\title{
Penggunaan Obat Tradisional oleh Penderita Diabetes Mellitus dan Faktor-faktor yang Berhubungan di Wilayah Kerja Puskesmas Rejosari Pekanbaru Tahun 2015
}

\section{The Use of Traditional Remedies by Diabetics Mellitus and Factors Associated in The Work Area Puskesmas Rejosari Pekanbaru 2015}

\author{
Emy Leonita*, Ariska Muliani**
}

*Dosen S1 Ilmu Kesehatan Masyarakat STIKes Hang Tuah Pekanbaru

**Alumni S1 Ilmu Kesehatan Masyarakat STIKes Hang Tuah Pekanbaru

\begin{abstract}
ABSTRAK
Diabetes mellitus merupakan penyakit yang dapat mengakibatkan kematian, saat ini pemerintah Indonesia menganjurkan masyarakat untuk mengkonsumsi obat berbahan tradisional karena mengingat efek sampingnya yang rendah salah satunya pengobatan DM. Berdasarkan rekapitulasi pencatatan data terkait penyakit DM diketahui jumlah pasien DM yang paling tertinggi terdapat di Puskemas Rejosari yaitu sebanyak 228 orang. Tujuan penelitian ini untuk mengetahui hubungan penggunaan obat tradisional oleh penderita diabetes mellitus dan faktor-faktor yang berhubungan di Wilayah Kerja Puskesmas Rejosari Pekanbaru tahun 2015. Jenis penelitian ini adalah kuantitatif analitik observasional dengan menggunakan desain Cross-sectional. Penelitian dilakukan pada bulan April hingga Juni 2015 di Wilayah Kerja Puskesmas Rejosari Pekanbaru. Populasi adalah seluruh pasien DM tipe II yang tinggal di wilayah Puskesmas Rejosari, jumlah sampel sebanyak 150 orang, sampel diambil dari catatan penderita dimulai dari waktu terdekat, pengolahan data menggunakan komputerisasi dan analisa dilakukan secara univariat dan bivariat dengan uji statistik chi square.Hasil penelitian diperoleh sebanyak 78 orang $(52,0 \%)$ menggunakan obat medis dan tradisional. Variabel yang berhubungan dengan penggunaan obat medis dan tradisional adalah pendidikan nilai $(\mathrm{CI}=1,3-5,1)$, motivasi diri nilai $(\mathrm{CI}=1,6-6,7)$, pendapatan $(\mathrm{CI}=1,4-5,4)$, dan kebudayaan nilai $(\mathrm{CI}=1,2-4,5)$. Diharapkan kepada Puskesmas Rejosari Pekanbaru untuk mengadakan program BATRA, memberikan informasi tentang jenis obat tradisional yang tepat untuk pengobatan DM, memberikan informasi dengan menggunakan testimony orang yang menggunakan obat medis dan tradisional.
\end{abstract}

\section{Kata Kunci: Diabetes Mellitus, obat tradisional}

\section{ABSTRACT}

Diabetes mellitus is a disease that can result in death, the current Government of Indonesia urged the public to consume the drug made from traditional because given the low side effects one of which treatment of DM. Based on a recapitulation of recording data related to disease dm known the number of patients dm most highest in public health center rejosari that is as much as the 228. The purpose of whether there is a traditional use of drugs by patients with diabetes mellitus and factors in the work that is associated puskesmas rejosari pekanbaru 2015. Type of this research is quantitative analytic observational by using Cross-sectional design. Research conducted in April to June 2015 in the region of clinics Rejosari Pekanbaru. The entire population is type II DM patients who live in the area of public health, the number of samples as much as Rejosari 150 people, sampling by taking note of the sufferer starts from the time closest to you, with the use of computerized data processing and analysis done in a univariate and bivariat with chi square statistical tests. The research results obtained as many as 78 people ( 52.0 $\%)$ have used traditional and medical cures. Variable are associated with the use of medical drugs and is the education and traditional $(C I=1,3-5,1)$, self motivation $(C I=1,6-6,7)$, income $P$ value $=(C I=1,4-5,4)$, and cultural $P$ value $=0.016,(C I=1,2-4,5)$.Is expected to puskesmas rejosari pekanbaru to hold the program BATRA, provided information about the type of traditional medicines appropriate for the treatment of DM, give testimony infirmasi by using people who use traditional medicine and medical.

Keywords: Diabetes mellitus, traditional medicines

${ }^{1}$ Alamat Korespodensi: Emy Leonita, Email: leonitaemy@yahoo.com 


\section{PENDAHULUAN}

Penyakit Diabetes Mellitus (DM) dikenal sebagai penyakit kencing manis atau penyakit gula darah adalah golongan penyakit kronis yang ditandai dengan peningkatan kadar gula dalam darah melebihi 150 $\mathrm{mg} / \mathrm{dl}$, dimana batas normal gula darah adalah 70-150 $\mathrm{mg} / \mathrm{dl}$, sebagai akibat adanya gangguan sistem metabolisme dalam tubuh, dimana organ pankreas tidak mampu memproduksi hormon insulin sesuai kebutuhan tubuh (Ernawati, 2013).

Penyakit diabetes merupakan penyakit yang dapat menurunkan kualitas hidup penderita hingga mengakibatkan kematian. Pengobatan yang dilakukan dalam jangka waktu panjang dan secara terus menerus akan berdampak pada finansial pasien diabetes mellitus tersebut, karena biaya pengobatan diabetes mellitus membutuhkan biaya yang besar (Ernawati, 2013).

World Organization Health (WHO) menyatakan, prevalensi DM meningkat dengan cepat pada dekade terakhir, sampai lebih dari 40\%. Peningkatan prevalensi obesitas lebih $60 \%$ dalam periode yang sama, berhubungan erat dengan perkembangan DM tipe 2 (Ernawati, 2013).

Menurut Sari (2013), Indonesia merupakan negara yang menduduki rangking keempat dari jumlah penyandang diabetes terbanyak setelah Amerika Serikat, China dan India. Selain itu, penderita DM di Indonesia diperkirakan akan meningkat pesat hingga 23 kali lipat pada tahun 2030 dibandingkan tahun 2000.

Berdasarkan laporan tahunan dinas kesehatan Provinsi Riau, mengenai penyakit tidak menular khususnya penyakit DM mengalami peningkatan setiap tahunnya. Hal ini dapat dilihat dari hasil rekapan penyakit DM tahun 2011 tercatat 489 kasus, tahun 2012 tercatat 586 kasus dan pada tahun 2013 kasus meningkat menjadi 507 kasus. (Profil Dinkes Provinsi Pekanbaru, 2013).

WHO tahun 2011, memperkirakan 105.536 industri obat tradisional di dunia, dan di Indonesia dari tahun ke tahun terjadi peningkatan produksi obat tradisional. Menurut Data Badan Pengawasan Obat dan Makanan (BPOM), sampai tahun 2011 terdapat 1.012 industri obat tradisional yang memiliki izin usaha industri yang terdiri dari 105 industri berskala besar dan 907 industri berskala kecil. Karena banyaknya variasi sediaan bahan alam, maka untuk memudahkan pengawasan dan perizinan, maka BPOM mengelompokan dalam sediaan jamu, sediaan herbal terstandar dan sediaan fitofarmaka. Persyaratan ketiga sediaan berbeda yaitu untuk jamu pemakaiannya secara empirik berdasarkan pengalaman, sediaan herbal terstandar bahan bakunya harus distandarisasi dan sudah diuji farmakologi secara eksperimental, sedangkan sediaan fitofarmaka sama dengan obat modern bahan bakunya harus distandarisasi dan harus melalui uji klinik (Soekamto, 2013).

Menurut Ernawati (2013), saat ini pemerintah Indonesia menganjurkan masyarakat untuk mengkonsumsi obat berbahan tradisional karena mengingat efek sampingnya yang rendah. Sedangkan menurut Sari (2013), ada beberapa faktor yang mempengaruhi masyarakat dalam memilih pengobatan yaitu tingkat pendidikan, motivasi diri dan sosial ekonomi. Tingkat pendidikan yang rendah berdampak pada pengetahuan seseorang dalam masalah kesehatan khususnya pengobatan DM. Umumnya orang yang berpendidikan tinggi akan lebih memilih menggunakan obat medis dan tradisional dibandingkan dengan obat medis saja. Selain itu, motivasi diri juga mempengaruhi orang dalam memilih pengobatan. Motivasi diri yang rendah dalam pengobatan medis mengakibatkan orang cenderung lebih memilih pengobatan tradisional. Rendahnya status ekonomi juga menjadi penyebab orang dalam memilih pengobatan tradisional, karena pengobatan tradisional lebih murah dibandingkan dengan obat medis. Menurut Yuka (2011), kebudayaan mempengaruhi masyarakat dalam memilih pengobatan tradisional. Hal ini dikarenakan kebudayaan didasari oleh turuntumurun dan dapat mempengaruhi keyakinan orang dalam menggunakan obat tradisional.

Menurut data Dinas Kesehatan Kota Pekanbaru (2013), jumlah penderita DM mengalami peningkatan setiap tahunnya, yaitu tahun 2010 sebanyak 1957 kasus, tahun 2011 sebanyak 2720 kasus dan tahun 2013 meningkat menjadi 2897 kasus. Berdasarkan rekapitulasi pencatatan data terkait penyakit DM dapat diketahui jumlah kunjungan pasien DM yang paling tinggi terdapat di Puskemas Rejosari yaitu sebanyak 2260 kunjungan. Berdasarkan data yang diperoleh langsung dari Puskesmas Rejosari Pekanbaru mengenai jumlah penderita DM yang terdaftar tercatat sebanyak yaitu sebanyak 228 penderita DM. Berdasarkan hal diatas peneliti tertarik untuk meneliti "Penggunaan Obat Tradisonal oleh Penderita Diabetes Mellitus dan Faktor-Faktor yang Berhubungan di Wilayah Kerja Puskesmas Rejosari Pekanbaru Tahun 2015".

\section{METODE PENELITIAN}

Jenis penelitian ini adalah analitik kuantitatif observasional dengan menggunakan desain analitik Cross-sectional. Penelitian dilakukan pada bulan April hingga Juni 2015 di Wilayah Kerja Puskesmas Rejosari Pekanbaru. Populasi adalah seluruh pasien DM tipe II yang tinggal di wilayah Puskesmas Rejosari, jumlah sampel sebanyak 150 orang dengan menggunakan tabel distribusi besar sampel, dan diambil dari catatan penderita dimulai dari waktu terdekat, dengan pengolahan data menggunakan 
komputerisasi dan analisa dilakukan secara univariat dan bivariat dengan uji statistik chi square.

Pengumpulan data dilakukan dengan cara menetapkan sampel yaitu pada hari pertama didapatkan sebanyak 7 orang, hari kedua 6 orang, hari ketiga 8 orang, hari ke empat 5 orang dan begitu seterusnya sesuai dengan jadwal kunjungan pasien sehingga jumlah sampel terpenuhi sebanyak 150 orang.

\section{HASIL PENELITIAN}

Analisis Univariat

Variabel Dependen

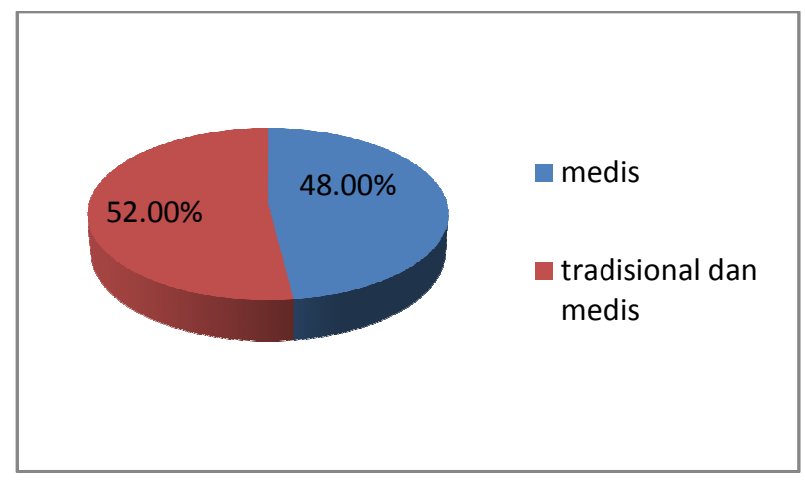

Variabel independen

Tabel 1

Hasil analisis univariat

\begin{tabular}{clcc}
\hline No & \multicolumn{1}{c}{ Variabel } & F & \% \\
\hline $\mathbf{1}$ & Pendidikan & & \\
& Rendah & 56 & 37,3 \\
& Tinggi & 94 & 62,7 \\
$\mathbf{2}$ & Motivasi diri & & \\
& Kurang & 49 & 32,7 \\
& Baik & 101 & 67,3 \\
$\mathbf{3}$ & Pendapatan & & \\
& Rendah & 70 & 46.7 \\
& Tinggi & 80 & 53,3 \\
$\mathbf{4}$ & Kebudayaan & & \\
& Negatif & 69 & 46,0 \\
& Positif & 81 & 54,0 \\
& $\quad$ Total & $\mathbf{1 5 0}$ & $\mathbf{1 0 0}$ \\
\hline
\end{tabular}

Berdasarkan tabel 1, dapat dilihat dari 150 responden pada penelitian ini didapatkan sebagian responden berpendidikan rendah sebanyak 56 orang $(37,3 \%)$, memiliki motivasi diri yang kurang sebanyak 49 orang $(32,7 \%)$, yang memiliki pendapatan rendah $70(46,7 \%)$, dan yang kebudayaan negative 69 (46\%).

Analisis Bivariat

Tabel 2

Hasil Analisis Bivariat

\begin{tabular}{|c|c|c|c|c|c|c|c|c|}
\hline \multirow[t]{2}{*}{$\begin{array}{c}\text { Tingkat } \\
\text { Pendidikan }\end{array}$} & \multicolumn{3}{|c|}{$\begin{array}{l}\text { Penggunaan Obat medis } \\
\text { dan tradisonal DM }\end{array}$} & \multirow[b]{2}{*}{$(\%)$} & \multirow[b]{2}{*}{ Total } & \multirow[b]{2}{*}{$(\%)$} & \multirow[t]{2}{*}{$\begin{array}{c}P \\
\text { value }\end{array}$} & \multirow[t]{2}{*}{$\begin{array}{c}\text { POR }_{(95 \%)} \\
\text { CI }\end{array}$} \\
\hline & Medis & $(\%)$ & $\begin{array}{l}\text { Medis dan } \\
\text { tradisional }\end{array}$ & & & & & \\
\hline Rendah & 35 & 62,5 & 21 & 37,5 & 56 & 100 & \multirow[t]{3}{*}{0,010} & \multirow{3}{*}{$\begin{array}{c}2,568(1,3- \\
5,1)\end{array}$} \\
\hline Tinggi & 37 & 39,4 & 57 & 60,6 & 94 & 100 & & \\
\hline Total & 72 & & 78 & & 150 & 100 & & \\
\hline \multicolumn{9}{|l|}{ Motivasi Diri } \\
\hline Kurang Baik & 33 & 67,3 & 16 & 32,7 & 49 & 100 & \multirow[t]{3}{*}{0,002} & \multirow{3}{*}{$\begin{array}{c}3,279(1,6- \\
6,7)\end{array}$} \\
\hline Baik & 39 & 38,6 & 62 & 61,4 & 101 & 100 & & \\
\hline Total & 72 & & 78 & & 150 & & & \\
\hline \multicolumn{9}{|l|}{ Pendapatan } \\
\hline Rendah & 43 & 61,4 & 27 & 38,8 & 70 & 100 & \multirow{2}{*}{0,004} & \multirow{3}{*}{$\begin{array}{c}2,801(1,4- \\
5,4)\end{array}$} \\
\hline Tinggi & 29 & 36,2 & 51 & 63,8 & 80 & 100 & & \\
\hline Total & 72 & & 78 & & 150 & & & \\
\hline \multicolumn{9}{|l|}{ Kebudayaan } \\
\hline Negatif & 41 & 59,4 & 28 & 40,6 & 69 & 100 & \multirow[t]{2}{*}{0,002} & \multirow{3}{*}{$\begin{array}{c}2,362(1,2- \\
4,5)\end{array}$} \\
\hline Positif & 31 & 38,3 & 50 & 61,7 & 81 & 100 & & \\
\hline Total & 72 & & 78 & & 150 & & & \\
\hline
\end{tabular}

Hasil uji statistik terhadap risiko didapat nilai $\mathrm{POR}=2,568$ pada $95 \% \mathrm{CI}=1,299-5,074$ ini berarti orang yang berpendidikan rendah mempunyai peluang 2,568 kali menggunakan obat medis saja dibanding dengan orang yang berpendidikan tinggi. Serta di dapat nilai $\mathrm{P}=0,010 \quad(\mathrm{p}<0,05)$ artinya terdapat hubungan antara pendidikan dengan penggunaan obat tradisional pada penderita DM.

Hasil uji statistik terhadap risiko didapat nilai $\mathrm{POR}=3,279$ pada $95 \% \mathrm{CI}=1,598-6,729)$ ini berarti 
orang yang memiliki motivasi diri kurang mempunyai peluang 3,279 kali menggunakan obat medis saja dibanding dengan orang yang memiliki motivasi diri yang baik. Serta di dapat nilai $p=0,002 \quad(p<0,05)$ artinya terdapat hubungan antara motivasi diri dengan penggunaan obat tradisional pada penderita DM.

Hasil uji statistik terhadap risiko didapat nilai $\mathrm{POR}=2,801$ pada $95 \% \mathrm{CI}=1,443-5,434)$ ini berarti orang yang memiliki pendapatan rendah mempunyai peluang 2,801 kali menggunakan obat medis saja dibanding dengan orang yang memiliki pendapatan tinggi. Serta di dapat nilai $\mathrm{P}=0,004(\mathrm{p}<0,05)$ artinya terdapat hubungan antara pendapatan dengan penggunaan obat tradisional pada penderita DM.

Hasil uji statistik terhadap risiko didapat nilai $\mathrm{POR}=2,362$ pada $95 \% \mathrm{CI}=1,224-4,556)$ ini berarti orang yang memiliki kebudayaan negatif mempunyai peluang 2,362 kali menggunakan obat medis saja dibanding dengan orang yang memiliki kebudayaan yang positif. Serta di dapat nilai $p=0,016 \quad(p<0,05)$ artinya terdapat hubungan antara kebudayaan dengan penggunaan obat tradisional pada penderita DM.

\section{PEMBAHASAN}

\section{Tingkat Pendidikan}

Terdapat hubungan yang signifikan antara tingkat pendidikan dengan penggunaan obat medis dan tradisonal pada penderita DM tipe II di Wilayah Kerja Puskesmas Rejosari Pekanbaru Tahun 2015.

Hasil penelitian ini sejalan dengan teori Notoatmodjo (2014), bahwa pendidikan diperlukan untuk mendapat informasi misalnya hal-hal yang menunjang kesehatan sehingga dapat meningkatkan kualitas hidup. Menurut YB Mantra yang dikutip. Selain itu menurut Nursalam (2003), bahwa pendidikan dapat mempengaruhi seseorang termasuk juga perilaku seseorang akan pola hidup. Pada umumnya makin tinggi pendidikan seseorang makin mudah menerima informasi.

Hasil penelitian ini sejalan dengan penelitian yang dilakukan Yuka (2011), dimana 57\% responden berpendidikan rendah menggunakan pengobatan tradisional. Sedangkan hasil analisa bivariat diperoleh $\mathrm{p}<0,05$ yang artinya terdapat hubungan antara pendidikan dengan penggunaan obat tradisional pada penderita DM.

Menurut asumsi peneliti, sebagian responden yang berpendidikan rendah menggunakan obat medis saja dikarenakan pendidikan yang rendah mengakibatkan sulitnya mendapatkan informasi tentang penggunaan obat tradisional. Selain itu, pendidikan responden yang rendah juga menjadi keterbatasan untuk mengetahui tentang penggunaan obat tradisional yang baik. Hal ini didukung oleh kenyataan dilapangan pada saat penelitian, banyak responden yang beranggapan obat medis lebih baik dibandingkan dengan obat tradisional karena obat medis diberikan lansung oleh dokter.

\section{Motivasi Diri}

Terdapat hubungan yang signifikan antara motivasi diri dengan penggunaan obat medis dan tradisional pada penderita DM tipe II di Wilayah Kerja Puskesmas Rejosari Pekanbaru Tahun 2015.

Menurut Adnani (2011), motivasi merupakan kekuatan (energi) seseorang yang dapat menimbulkan tingkat persistensi dan antusiasnya dalam melaksanakan suatu kegiatan, baik yang bersumber dari dalam diri individu itu sendiri (motivasi intrinsik) maupun dari luar individu (motivasi ekstrinsik). Seberapa kuat motivasi yang dimiliki individu akan banyak menentukan terhadap kualitas perilaku yang ditampilkannya, baik dalam konteks belajar, bekerja maupun dalam kehidupan lainnya. Kajian tentang motivasi telah sejak lama memiliki daya tarik tersendiri bagi kalangan pendidik, manajer, dan peneliti.

Hal ini sejalan dengan penelitian Sartika (2010), yang bertujuan untuk mengetahui faktor-faktor yang berhubungan dengan pengobatan tradisional untuk penyembuhan penyakit pada pasien DM di Wilayah Kerja Puskesmas Delima Kabupaten Banjar Negara, diperoleh hasil analisa bivariat $\mathrm{p}<0,05$ yang artinya terdapat hubungan antara motivasi dengan pengobatan tradisional.

Menurut peneliti, adanya hubungan antara motivasi diri disebabkan karena sebagian responden memiliki motivasi diri yang kurang, sehingga responden cenderung memilih pengobatan medis saja. Selain itu, dari hasil kenyatan dilapangan banyak responden yang mengaku tidak tertarik untuk menggunakan obat tradisional, karena mereka beranggapan obat medis lebih praktis dibandingkan obat tradisional yang harus di olah terdahulu sebelum dikonsumsi.

\section{Pendapatan}

Terdapat hubungan yang signifikan antara pendapatan dengan penggunaan obat medis dan tradisional pada penderita DM tipe II di Wilayah Kerja Puskesmas Rejosari Pekanbaru Tahun 2015.

Menurut Djaya (2011), pendapatan adalah penghasilan yang diperoleh dari seseorang untuk memenuhi kebutuhan hidupnya. Pendapatan sering dikaitkan dengan status ekonomi. Status ekonomi adalah kedudukan atau posisi seseorang dalam masyarakat, status sosial ekonomi adalah gambaran tentang keadaan seseorang atau suatu masyarakat yang ditinjau dari segi sosial ekonomi.

Menurut Utamadi (2011), status ekonomi merupakan faktor utama dalam mendapatkan pelayanan kesehatan termasuk pengobatan. Menurut penelitian Yuka (2011), didapatkan hasil $p<0,05$. Hal ini berarti terdapat hubungan yang signifikan antara 
status ekonomi dengan penggunaan obat tradisional pada penderita DM.

Menurut asumsi peneliti, banyak responden yang menggunakan pengobatan medis dan tradisional, hal ini disebabkan karena setelah berobat kepuskesmas mereka juga dapat menggunakan obat tradisonal di rumah tanpa biaya tambahan. Akan tetapi dari hasil penelitian diketahui sebagai responden masih ada yang hanya menggunakan obat medis saja, hal ini didukung oleh pendatapan mereka yang tinggi, sehingga mereka dapat memperoleh obat medis yang lebih praktis.

\section{Kebudayaan}

Terdapat hubungan yang signifikan antara kebudayaan dengan penggunaan obat medis dan tradisional pada penderita DM tipe II di Wilayah Kerja Puskesmas Rejosari Tahun 2015.

Menurut Hidayat (2011), kebudayaan sangat mempengaruhi masyarakat dalam memiliki pengobatan. Hal ini disebabkan karena kebudayaan yang didasari oleh turun-temurun dan dapat mempengaruhi keyakinan orang dalam menggunakan pengobatan.

Hal ini sejalan dengan penelitian Sartika (2010), yang bertujuan untuk mengetahui faktor-faktor yang mempengaruhi masyarakat dalam memilih pengobatan tradisional pada pasien DM Di Wilayah Kerja Puskesmas Delima Kabupaten Banjar Negara, diperoleh hasil $p<0,05$ yang artinya terdapat pengaruh antara kebudayaan terhadap pengobatan tradisional.

Menurut asumsi peneliti, sebagian besar responden yang berkebudayaan negatif menggunakan obat medis saja dikarenakan kebiasaan mereka bahwa berobat medis saja sudah cukup untuk menormalkan gula darah, tanpa memerhatikan efek samping dari penggunaan obat medis. Selain itu, adanya pengalaman dari keluarga mengajarkan mereka untuk menggunakan obat medis dan tradisional dengan tujuan untuk penatalaksanaan penyakit DM.

\section{KESIMPULAN}

Berdasarkan hasil penelitian yang telah dilakukan tentang Penggunaan Obat Tradisional Oleh Penderita DM dan Faktor-Faktor Yang Berhubungan di Wilayah Kerja Puskesmas Rejosari Pekanbaru Tahun 2015, dapat disimpulkan bahwa proporsi masyarakat yang menggunakan pengobatan tradisional dan medis sebanyak 78 orang $(52,0 \%)$ subjek penelitian. Adapun faktor-faktor yang berhubungan dengan penggunaan obat tradisional oleh penderita DM adalah Tingkat Pendidikan penderita DM tipe II, Motivasi diri penderita DM tipe II, Pendapatan Penderita DM tipe II dan Kebudayaan Penderita DM tipe II.

\section{SARAN}

\section{Bagi Puskesmas Rejosari}

Diharapkan kepada Puskesmas Rejosari Pekanbaru dapat meningkatkan pelayanan kesehatan dengan cara memberikan penyuluhan secara berkelanjutan dengan memperbanyak poster tentang pengobatan DM baik secara tradisional maupun secara medis diruang tunggu pasien sebagai salah satu upaya untuk meningkatkan perilaku dalam mencegah peningkatan gula darah pada penderita DM khususnya wilayah kerja Puskesmas Rejosari Pekanbaru. Diharapkan kepada Puskesmas Rejosari segera mengadakan program BATRA agar obat tradisional dapat dipertahankan. Kepada petugas kesehatan untuk memberikan informasi kepada masyarakat tentang jenis obat tradisional yang tepat untuk pengobatan penyakit DM dan mendukung masyarakat untuk menggunakan obat tradisional, serta memberitahukan cara penggunaan obat tradisional yang benar tanpa mengkesampingkan budaya dan memberikan informasi dengan testimoni orang-orang yang sebelumnya menggunakan obat medis dan tradisional.

\section{Penelitian Lainnya}

Diharapkan bagi peneliti selanjutnya dapat menggali informasi yang lebih dalam lagi tentang faktor yang berhubungan dengan penggunaan obat tradisional pada penderita DM dengan menggunakan metode penelitian kualitatif dan pengumpulan data dapat dilakukan dengan melakukan wawancara secara mendalam agar dapat diketahuinya jenis obat tradisional yang paling baik untuk pengobatan DM dan sering digunakan dan melakukan penelitian dengan variabel independen yang berbeda seperti sikap, dukungan keluarga, dukungan petugas kesehatan dan lainnya.

\section{DAFTAR PUSTAKA}

Djaya.(2011). Faktor-Faktor Yang Mempengaruhi Sosial Ekonomi. Diperoleh pada 23 Januari 2015. http: www.info kesehatan.com-76//west.

Ernawati. (2013). Pelaksanaan Keperawatan Diabetes Mellitus Terpadu. Jakarta : Mitra Wacana Medika.

Sartika.(2010).Faktor-Faktor Yang Berhubungan Dengan Pengobatan Tradisional Untuk penyembuhan Penyakit Pada Pasien Diabetes Mellitus Di Wilayah Kerja Puskesmas Delima Kabupaten Banjar Negara. Diperoleh pada 21 April 2015. http://jom.undip.aid/ vo,T4546-pdfjurnal kesehatan.

Notoatmodjo,S. (2010). Metode Penelitian Kesehatan. Jakarta : ECG. 
Nursalam. (2003). Pendidikan Dalam Pengetahuan. Diperoleh pada 25 Februari 2015. http: www.infokesehatan.com.

Profil Dinas Kesehatan Provinsi Riau Tahun 2013.

Sari,R. (2013). Diabetes Mellitus. Yoyakarta : Nuha Medika.

Sumardi. (2011). Faktor-Faktor Yang Mempengaruhi Pengetahuan. Diperoleh pada 23 Januari 2015. http: www.infokesehatan.com76//west.
Tjahjadi, v. (2010). Mengenal, Mencegah, Megatasi Killer Diabetes.Semarang : Pustaka Widyamara.

Utamadi. (2011). Faktor-Faktor Yang Mempengaruhi Pengetahuan. Diperoleh pada 23 Januari 2015. http: www. info kesehatan. com$76 / /$ west.

Yuka. (2011). Faktor -Faktor Yang Berhubungan Dengan Penggunaan Obat Tradisonal Pada Penderita DM Di Wilayah Kerja Puskesmas Buleleng Kecamatan Buleleng. Diperoleh pada 23 Januari 2015. http: www.pdf.jurnal kesehatan. com987-vol.1234. 